\title{
Understanding Depression
}

\author{
Lubhana Malik Mental* \\ Department of Psychology, University of Delhi, India
}

Submission: Febuary 25, 2019; Published: March 05, 2019

*Corresponding author: Lubhana Malik Mental, Department of Psychology, University of Delhi, India

Keywords: Depression; Legitimate; Biological; Concentrating; Struggling; Unmotivated

\section{Opinion}

"It feels like a haze, a fog, a cloud that has enveloped my mind. My brain does not function. I have stopped feeling anything. It is not just that I feel low, I feel NUMB; I do not feel any emotion positive or negative." - In the words of a client when she began treatment for Depression

Depression has received a lot of press in recent times with many celebrities publicly owing up to this feeling. In common parlance, depression is often misused to simply describe a feeling of sadness. While Depression can be called the 'Hero of Mental Health", it's not something to be glorified. It's not beautiful. Depression symptoms take many forms, and no two people's experiences are exactly alike. A person who is suffering from this condition may not seem sad to others. He/she may instead complain about how they just "can't get moving," or are "feeling completely unmotivated to do just about anything". Even simple things like getting dressed in the morning or eating become large obstacles in their daily lives. People around them, such as their friends and family, can also notice the change.

Although at times, the term depression is used frivolously or is trivialized, depression is not feeling down for an hour out of your day or feeling upset every now and then. Some people even go to the extent of disagreeing with the fact that depression is a real illness. However, the truth is that depression is a legitimate medical condition that is related to brain chemistry, function, and structure, and sometimes involves environmental or biological factors also. It is definitely not at all 'in your head' and it can affect anyone, regardless of their physical or mental strength. It is most definitely not a sign of weakness because it takes a great amount of courage to open your heart out and tell people what you are feeling and struggling all the while to put up a show of normalness in your day to day activities.

\section{Signs of depression are:}
a. Persistent sad or anxious mood
b. Restlessness, irritability
c. Feelings of hopelessness, pessimism, emptiness
d. Feelings of guilt, worthlessness, helplessness
e. Decreased energy, fatigue, being 'slow', exhausted
f. Difficulty concentrating, remembering, or making decisions

g. Insomnia, early-morning awakening, or oversleeping

h. Appetite and/or weight loss or overeating and weight gain

i. Thoughts of death or suicide; suicide attempts

j. Loss of interest or pleasure in hobbies and activities that were once enjoyed, including sex

k. Persistent physical symptoms that do not respond to treatment, such as headaches, digestive disorders, and chronic pain

Depression is $97 \%$ curable through psycho-therapy (talk therapy). The process of therapy works in a 'domino effect' manner. It starts by helping you by removing the haze/ numbness, so that you start to get your normal feelings back. This in turn helps to understand who you are and what choice you would like to make (identity related thoughts). This gives you a sense of self-assuredness, which helps to build self-confidence and the ability to love your-self. This further brings back your sense of motivation, interest and purpose in life. Feelings of loneliness 
and aloneness also start to reduce. You are now able to build an instinct that can help you gauge and differentiate, in a rational manner, between reality and perception. For example, you can now gauge what is really triggering your depression v/s what is a perceived trigger. This in turn reduces your sad and upset feelings and emotional outburst like crying, and you start to heal from your emotional and mental wounds.

So, if you feel that there is no reason to get out of bed, feel like crying for no reason, feel exhausted all the time, feel like sleeping all day or suffer from insomnia, overwhelmed with emotions, feel irritable, empty, hopeless and helpless, or if you are experiencing any of the other above-stated signs of depression on a prolonged basis, it is imperative that you seek professional help. Therapy can help you make progress/improvement in normal day-to-day functions and regain a passion for life!!!!

"It feels the haze or fog has started to lift. I am no longer numb. In the beginning, it was like a flood of feeling but gradually I am able to feel all types of emotions- happy, sad, angry etc. To be able to feel .... Makes me happy. Now I feel that I am confident enough so what other people say or think does not matter as much, rather what I feel is more important. Earlier I gave more than I had, now I feel I invest some in myself and give some, so I will be able to give much more like this. I am less exhausted, more motivated and more respectful of myself..." - in the words of the same client during treatment for Depression.

\begin{tabular}{l} 
Your next submission with Juniper Publishers \\
will reach you the below assets \\
- Quality Editorial service \\
- Swift Peer Review \\
- Reprints availability \\
- E-prints Service \\
- Manuscript Podcast for convenient understanding \\
- Global attainment for your research \\
- Manuscript accessibility in different formats \\
( Pdf, E-pub, Full Text, Audio) \\
- Unceasing customer service \\
Track the below URL for one-step submission \\
https://juniperpublishers.com/online-submission.php \\
\hline
\end{tabular}

